\title{
Inwentarz do Oceny Płci Psychologicznej - zaktualizowana charakterystyka psychometryczna $^{1}$
}

\begin{abstract}
Artykuł przedstawia charakterystykę psychometryczną Inwentarza do Oceny Płci Psychologicznej, której autorką jest Alicja Kuczyńska. Sprawdzono jakie określenia wchodzą w obecny stereotyp kobiecości i męskości. Wyniki uzyskane w badaniu własnym zestawiono z tymi, które pochodzą z analizy Renaty Korzeń, autorki artykułu: Nowa charakterystyka psychometryczna Inwentarza do Oceny Ptci Psychologicznej (IPP) (2006). Założono, że określenia pochodzące z Inwentarza mogły stać się nieaktualne. Dokonano eksploracyjnej analizy czynnikowej, metodą głównych składowych, pozycji pochodzących z IPP. Dzięki temu określono strukturę wewnętrzną skal Kuczyńskiej. Ostatecznie uzyskano dwa czynniki, wyjaśniające 30,51\% całkowitej wariancji. Wykonano analizę z rotacją ortogonalną czynników w metodzie Varimax. Finalnie, skale zostały zasilone przez pozycje z ładunkiem czynnikowym przekraczającym 0.3. Istniejące narzędzie ma zadowalające własności psychometryczne. Interpretacja ładunków czynnikowych poszczególnych pozycji IPP rzuca nowe światło na współczesne definicje kobiecości i męskości.
\end{abstract}

\section{Opis oryginalnego narzędzia}

Pojęcie gender ma szeroki zakres. Mowa tu o cechach osobowości, wzorcach zachowania, podejmowanych rolach płciowych czy stereotypach. Wszystkie wymienione stanowią pewną całość, która odnosi się do wymiarów męskości i kobiecości. Określenie to pierwotnie stosowane niejako w kontrze do „natury”, dzisiaj jest jej „nadbudową”. To co wydaje się być istotnym, jest ono „społeczną manifestacją” tożsamości płciowej rozumianej jako „świadomość bycia mężczyzną lub kobietą” (Seligman, Walker, Rosenhan, 2003, s. 574). W artykule tym mowa o płci psychologicznej w rozumieniu Alicji Kuczyńskiej.

Inwentarz do będą Oceny Płci Psychologicznej został stworzony przez Alicję Kuczyńską. Został on opublikowany w 1992 roku. IPP jest polskim odpowiednikiem narzędzia BSRI autorstwa Sandry L. Bem, w związku z tym, w swych założeniach opiera się na teorii schematów płciowych. Autorka ta pojęcie ang. gender tłumaczy jako płeć psychologiczną, którą rozumie jako: „spontaniczną gotowość do posługiwania się wymiarem płci w odniesieniu do siebie i świata” (Kuczyńska, 1992, s. 5). Wskazuje na cztery jej typy, są

\footnotetext{
* Adres do korespondencji: Jakub Błajet, Jakub.blajet@gmail.com.

${ }^{1}$ Raport z badania został napisany na podstawie pracy magisterskiej „Walidacja skali do pomiaru płci psychologicznej", napisanej w Instytucie Psychologii Uniwersytetu im. Adama Mickiewicza w Poznaniu. Promotorem pracy była prof. dr hab. Elżbieta Hornowska, recenzentem - prof. dr hab. Władysław Paluchowski.
} 
to: osoby określone seksualnie (ang. sex-typed), osoby androgyniczne, osoby nieokreślone seksualnie (ang. undifferentiated) oraz osoby krzyżowo określone seksualnie (ang. cross-sextyped) (Kuczyńska, 1992). Pojęcie płci psychologicznej zdaje się być węższym ujęciem niż rodzaj czy płeć społeczno-kulturowa. Koncentruje się na procesach psychicznych, poznawczym przetwarzaniu informacji związanych z płcią. Brak, w tym ujęciu odniesień, do związanych z rodzajem atrybutów, zachowań, ról społecznych, itp., kojarzonych z kobiecością i męskością. Ponadto, Kuczyńska opisując kobiecość i męskość, posługuje się określeniem ,płeć” co może być mylące, ponieważ sugeruje to biologiczne rozumienie owego słowa. Jednakże „,zawiłości” związane z rozumieniem pojęcia ang. gender nie są tematem tego artykułu. Koncentruje się on na psychometrycznych właściwościach Inwentarza Kuczyńskiej.

\section{Proces powstawania IPP}

Poniższy fragment, w całości, opisuje etapy powstawania oryginalnego narzędzia IPP, tj. Inwentarza do Oceny Płci Psychologicznej. Przedstawia w jaki sposób A. Kuczyńska stworzyła autorskie narzędzie.

Pierwsza lista określeń, opisujących kobiety oraz mężczyzn zawierała 141 cech. Pochodziła z literatury oraz propozycji studentów. Następnie poproszono 30 studentów oraz 30 studentek o ocenę owych pozycji pod kątem ich rozpowszechnienia w populacji polskich kobiet i mężczyzn. Tak więc, ich zadanie polegało na ocenieniu jaki procent mężczyzn i kobiet opisuje siebie poprzez daną cechę (Kuczyńska, 1992). Wyniki poddano analizie statystycznej i tak sprawdzono, które określenia są typowe dla obu płci. Podobnie jak u Bem, dana cecha musiała zostać uznana za „męską” zarówno przez kobiety jak i mężczyzn. Okazało się, że więcej określeń zasiliło stereotyp męskości (Kuczyńska, 1992). Ostatecznie, w eksperymentalnej wersji Inwentarza znalazło się po 18 przymiotników w skali Kobiecości i skali Męskości. Tak więc znalazło się w niej 45 cech, z czego 9 pochodziło ze skali Neutralnej. Badani mieli za zadanie zaznaczyć na 5-stopniowej skali Likerta, w jakim stopniu dana cecha ich charakteryzuje. Najniższa wartość w skali 1. Oznacza: „zupetnie taki nie jestem” a najwyższa: 5. „taki właśnie jestem” (Kuczyńska, 1992, s. 19). Wersją tą przebadano łącznie 79 studentów i studentek. Ostatecznie pozycje zostały poddane analizie mocy dyskryminacyjnej. Usunięto te, których wartość phi nie przekraczała 0,23 gdzie $\alpha=0,05$ (Kuczyńska, 1992). Ostateczna wersja narzędzia zawiera 35 określeń, z czego 5 znajduje się w skali Neutralnej. 
Tabela 1

Pozycje zasilające skale: Kobiecości, Męskości oraz Neutralna

\begin{tabular}{|c|c|c|}
\hline Skala Kobiecości & Skala Męskości & Skala Neutralna \\
\hline Wrażliwy & Dominujący & Odpowiedzialny \\
\hline Troskliwy & Niezależny & Przyjacielski \\
\hline $\begin{array}{c}\text { Angażujący się w sprawy } \\
\text { innych }\end{array}$ & Rywalizujący & Wiarygodny \\
\hline Łagodny & Nastawiony na sukces & Tolerancyjny \\
\hline Kokieteryjny & Mający siłę przebicia & Sympatyczny \\
\hline Dbający o swój wygląd & Łatwo podejmujący decyzję & \\
\hline Gospodarny & Arogancki & \\
\hline Mający poczucie estetyki & Mający dobrą kondycję fizyczną & \\
\hline Gderliwy & $\mathrm{Z}$ poczuciem humoru & \\
\hline Czuły & $\begin{array}{c}\text { Mający zdolność } \\
\text { przekonywania }\end{array}$ & \\
\hline Uczuciowy & Pewny siebie & \\
\hline Wrażliwy na potrzeby innych & Samowystarczalny & \\
\hline Zdolny do poświęceń & $\begin{array}{l}\text { Otwarty na świat zdarzeń } \\
\text { zewnętrznych }\end{array}$ & \\
\hline Delikatny & $\begin{array}{l}\text { Eksperymentujący w życiu } \\
\text { seksualnym }\end{array}$ & \\
\hline Naiwny & Sprytny & \\
\hline
\end{tabular}

Źródło: opracowanie własne

Pozycje mają formę przymiotnikową. Zostały sformułowane w formie męskiej. Zarówno w skali Kobiecości jak i Męskości znajdują się określenia, które mają negatywny wydźwięk, np. gderliwy, naiwny, arogancki, np.

Osoba badana jest proszona o ustosunkowanie się do 35 pozycji. Ma odpowiedzieć w jakim stopniu każda z cech opisuje jego/jej osobę. Zaznacza odpowiedź na 5-stopniowej skali Likerta, gdzie 1. oznacza: „Zupetnie taki nie jestem” a 5.: „Taki wtaśnie jestem”. Wyniki oblicza się oddzielnie dla skal: Kobiecości i Męskości, sumując punkty przydzielone każdej odpowiedzi (Kuczyńska, 1992). Określeniu typu płci psychologicznej służy tabela poniżej. Wartości, które się w niej znajdują wynikają z median uzyskanych w badaniu studentów (Kuczyńska, 1992). 
Tabela 2

Określanie typu płci psychologicznej na podstawie uzyskanych wyników

\begin{tabular}{|c|c|c|c|}
\hline & \multirow{2}{*}{ Liczba punktów } & \multicolumn{2}{|c|}{ Kobiecość } \\
\hline & & $0-51$ & $52-75$ \\
\hline \multirow{2}{*}{ 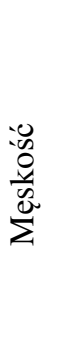 } & $0-48$ & $\begin{array}{l}\text { Osoby nieokreślone } \\
\text { seksualnie }\end{array}$ & $\begin{array}{l}\text { Kobiece kobiety } \\
\text { Kobiecy mężczyźni }\end{array}$ \\
\hline & $49-75$ & $\begin{array}{l}\text { Męscy mężczyźni } \\
\text { Męskie kobiety }\end{array}$ & Osoby androgyniczne \\
\hline
\end{tabular}

Źródło: Kuczyńska, 1992, s. 26

Analizy rzetelności IPP dokonano na podstawie badania 79 studentów eksperymentalną wersją owego narzędzia. Do analizy rzetelności wykorzystano odpowiedzi na te pozycje, które znalazły się w ostatecznej wersji narzędzia (Kuczyńska, 1992). Wykorzystano metodę estymacji wewnętrznej zgodności testu, z wykorzystaniem wzoru Kudera-Richardsona, w adaptacji Fergusona (Brzeziński, 1978, za: Kuczyńska, 1992). Jak podaje Kuczyńska dla skali Męskości $r_{t t}=0,7834$, z kolei dla Kobiecości: $r_{t t}=0,7856$ (1992). Jeśli chodzi o standardowy błąd pomiaru, w skali Kobiecości jest on równy 3,36, a w Męskości 3,75 (Kuczyńska, 1992).

Kuczyńska analizowała trafność teoretyczną swojego narzędzia. W tym celu przebadała osoby transseksualne, opierając się na założeniu mówiącym o występowaniu u nich niezgodności pomiędzy jednostkowym poczuciem płci a płcią $\mathrm{w}$ rozumieniu biologicznym. Wyszła z założenia, że owa rozbieżność prowadząca do psychicznego dyskomfortu, skłania osoby transseksualne do jego zredukowania poprzez chirurgiczną korektę płci. Ponadto, wg autorki, mają one tendencję do podejmowania zachowań, ról społecznych czy przyjmowania atrybutów zgodnych $\mathrm{z}$ ich poczuciem płci psychicznej (Kuczyńska, 1992). Założenie to wydaje się być nadmiernym uproszczeniem. Zakładanie, że osoba transseksualna, np. o typie K/M osiągnie wyniki zbliżone do mężczyzn może być błędne. Jednakże Kuczyńska właśnie tak sformułowała swoją hipotezę jeśli chodzi o trafność teoretyczną. Wyniki osób transseksualnych $(\mathrm{K} / \mathrm{M})$ porównała $\mathrm{z}$ wynikami studentów (Kuczyńska, 1992). Nie analizowała posiadanej przez nich płci psychologicznej. Stwierdziła 
tylko, że posiadanie przez nich płci psychologicznej określonej konwencjonalnie, jest mało prawdopodobne (Kuczyńska, 1992). By porównać owe grupy autorka zastosowała test tStudenta (Kuczyńska, 1992).

Tabela 3

Porównanie wyników osób transseksualnych i studentów - trafność teoretyczna

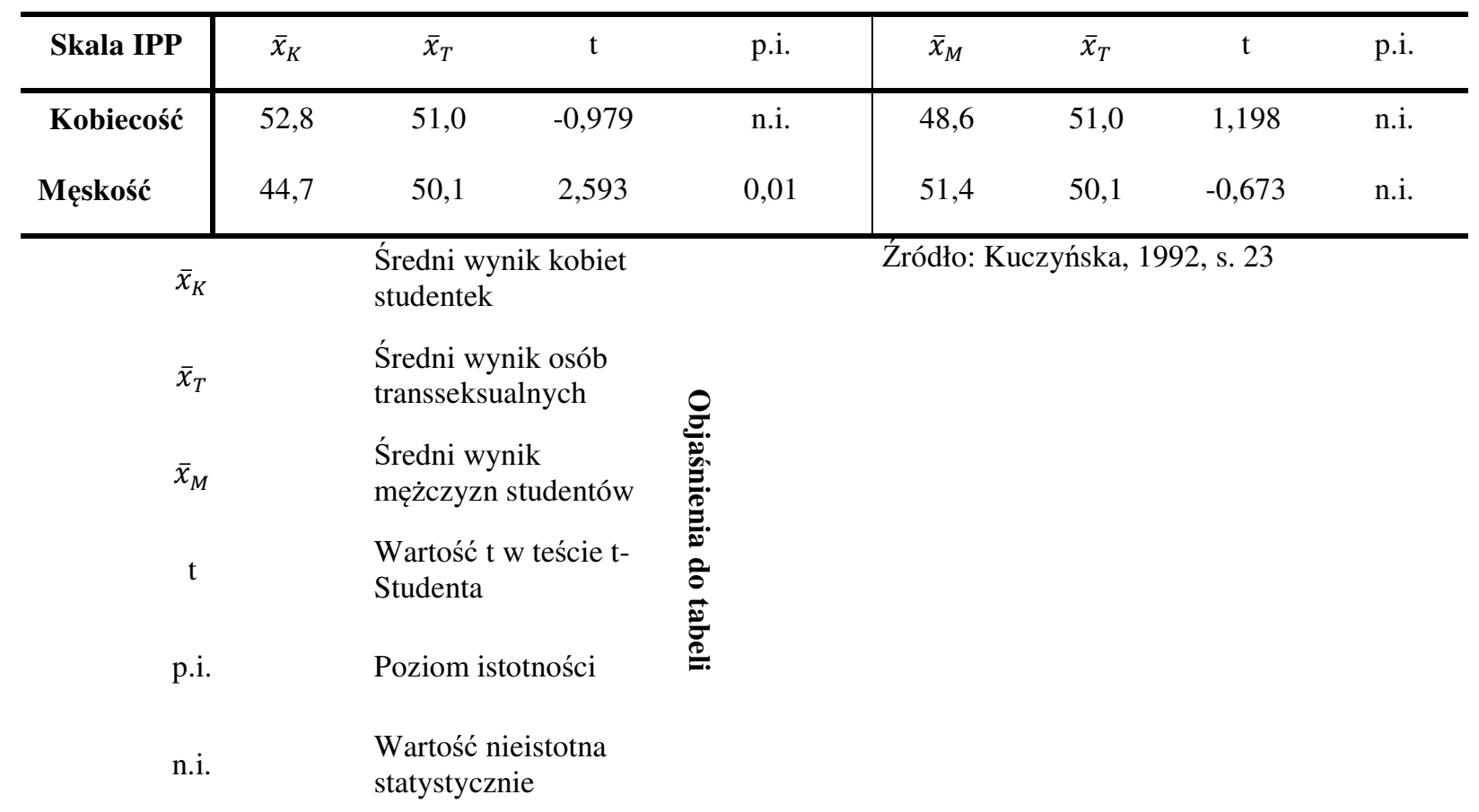

Z powyższej tabeli wynika, że w skali Kobiecości zarówno wyniki kobiet jak i mężczyzn nie różnią się od wyników kobiet transseksualnych. Z kolei, wyniki osób transseksualnych $(\mathrm{K} / \mathrm{M})$, w skali Męskości, różnią się od wyników studentek, ale nie różnią się od wyników studentów (Kuczyńska, 1992). Wyżej omówiona hipoteza, znalazła wg autorki swoje potwierdzenie, w związku z tym uznała to narzędzie za trafne teoretycznie. Warto jednak pamiętać, że od wydania tego narzędzia minęło ponad 10 lat, dlatego należy się zastanowić czy narzędzie jest dalej rzetelne i trafne.

\section{Badanie własne}

W badaniu własnym skoncentrowano się na analizie rzetelności oraz trafności IPP. Udział w nim wzięły 132 kobiety oraz 63 mężczyzn. Łącznie badanych było 195 . Byli to studenci w wieku: 19-26, z różnych uczelni w Polsce. Badani zostali poproszeni o wypełnienie Inwentarza do Oceny Płci Psychologicznej. 


\section{Uzyskane wyniki}

Pierwszym krokiem było dokonanie eksploracyjnej analizy czynnikowej, metodą głównych składowych, pozycji pochodzących z oryginalnego Inwentarza do oceny Płci Psychologicznej. Tak by możliwe było określenie struktury wewnętrznej skal autorstwa A. Kuczyńskiej. Liczbę czynników wyodrębniono na podstawie kryterium wykresu osypiska. Dzięki temu uzyskano dwa czynniki, wyjaśniające 30,51\% całkowitej wariancji. Wykonano analizę z rotacją ortogonalną czynników w metodzie Varimax. Skale zostały zasilone przez pozycje z ładunkiem czynnikowym przekraczającym 0.3. Dzięki temu ustalono, że do skali Kobiecości weszły takie określenia jak: wrażliwy $(0,65)$, troskliwy $(0,68)$, angażujący się w sprawy innych (0,61), tagodny (0,53), mający poczucie estetyki $(0,31)$, wrażliwy na potrzeby innych $(0,66)$, zdolny do poświęceń $(0,43)$, delikatny $(\mathbf{0 , 7 2})$, uczuciowy $(\mathbf{0 , 7 1})$, czuły $(\mathbf{0 , 7 3}) . \mathrm{Z}$ kolei do Męskości: dominujący (0,54), niezależny (0,34), rywalizujący $(0,33)$, nastawiony na sukces $(0,55)$, kokieteryjny $(0,39)$, mający siłe przebicia $(\mathbf{0 , 7 1})$, tatwo podejmujacy decyzje (0,58), dbający o swój wygląd (0,35), gospodarny (0,43), mający dobra kondycje fizyczna (0,34), z poczuciem humoru (0,34), sprytny $(0,63)$, majacy zdolność przekonywania $(0,64)$, pewny siebie $(\mathbf{0 , 7 2})$, samowystarczalny $(0,38)$, otwarty na świat zdarzeń zewnętrznych $(0,46)$, eksperymentujacy $w$ życiu seksualnym $(0,34)$. Podobnie jak w pierwotnej wersji inwentarza (Kuczyńska, 1992) stereotyp męskości obfituje w większą liczbę określeń go charakteryzujących. W wersji eksperymentalnej oryginalnego narzędzia skalę Męskości zasilały 32 pozycje, gdzie Kobiecość tylko 12 (Kuczyńska, 1992).

Tabela 4

Macierz rotowanych składowych - IPP A. Kuczyńskiej (1992)

\begin{tabular}{lcc}
\hline & \multicolumn{2}{c}{ Składowa } \\
\cline { 2 - 3 } 17. Dominujący & \multicolumn{1}{c}{2} \\
18. Wrażliwy & &, 651 \\
19. Angażujący się w sprawy innych & &, 613 \\
20. Niezależny &, 343 & \\
21. Troskliwy & &, 681 \\
22. Łagodny & &, 534 \\
23. Rywalizujący &, 329 & \\
24. Nastawiony na sukces &, 550 & \\
25. Kokieteryjny &, 390 & \\
26. Mający siłę przebicia &, 708 & \\
27. Łatwo podejmujący decyzję &, 580 &
\end{tabular}




\begin{tabular}{|c|c|c|}
\hline & \multicolumn{2}{|c|}{ Składowa } \\
\hline & 1 & 2 \\
\hline 28. Dbający o swój wygląd & ,349 & \\
\hline 29. Gospodarny & ,428 & \\
\hline 30. Arogancki & &,- 497 \\
\hline 31. Uczuciowy & & ,705 \\
\hline 32. Mający dobrą kondycję fizyczną &, 343 & \\
\hline 33. Gderliwy & & \\
\hline 34. $\mathrm{Z}$ poczuciem humoru &, 335 & \\
\hline 35. Sprytny & ,630 & \\
\hline 36. Mający zdolność przekonywania & ,641 & \\
\hline 37. Mający poczucie estetyki & & ,311 \\
\hline 38. Pewny siebie &, 722 & \\
\hline 39. Wrażliwy na potrzeby innych & & 655 \\
\hline 40. Samowystarczalny & ,376 & \\
\hline 41. Zdolny do poświęceń & & ,430 \\
\hline 42. Otwarty na świat zdarzeń zewnętrznych & 456 & ,377 \\
\hline 43. Delikatny & & ,723 \\
\hline 44. Eksperymentujący w życiu seksualnym & ,339 & \\
\hline 45. Naiwny &,- 347 & \\
\hline 46. Czuły & & ,729 \\
\hline
\end{tabular}

Metoda wyodrębniania czynników - Głównych składowych.

Metoda rotacji - Varimax z normalizacją Kaisera. ${ }^{a}$

a. Rotacja osiągnęła zbieżność w 3 iteracjach.

Obydwa czynniki Kobiecość i Męskość mają podobną siłę. Męskość została zasilona przez 17 pozycji, z kolei na Kobiecość składa się 10 przymiotników. I czynnik tłumaczył $15,5 \%$ wariancji a II $15,02 \%$.

W skali Kobiecości 3 pozycje: delikatny, uczuciowy, czuły mają najwyższe ładunki, oscylujące wokół wartości 0,70. Najniższy ładunek ma pozycja: mający poczucie estetyki $(0,31)$. Przy pozostałych pozycjach ładunki mają wartości w przedziale od 0,43 do 0,73. Przy czym pozycje kokieteryjny $(0,39)$, dbajacy o swój wygląd $(0,35)$ oraz gospodarny $(0,43)$ zasiliły Męskość, określenie: naiwny (-0,35) niejako też przez swoją odwrotność. Pozycja gderliwy nie zasiliła żadnego z dwóch czynników.

W skali Męskości wyróżnić można 17 pozycji. W jej skład weszły pozycje, które w oryginalnym IPP A. Kuczyńskiej wchodziły w skład skali: Kobiecość, czyli: kokieteryjny $(0,39)$, dbający o swój wygląd (0,35), gospodarny (0,43). Pozycja: arogancki „wypadła” z owej skali. Wyróżnić można dwie pozycje o najwyższych ładunkach, mianowicie: pewny siebie $(0,72)$ oraz majacy siłe przebicia $(0,71)$. Ładunki czynnikowe pozostałych określeń 
oscylują w przedziale: od 0,3 do 0,4, a więc są stosunkowo niskie (niezależny, rywalizujący, kokieteryjny, dbający o swój wygląd, mający dobra kondycje fizyczną, z poczuciem humoru, samowystarczalny, eksperymentujący w życiu seksualnym).

Przy interpretacji tych danych posłużono się badaniami Renaty Korzeń (2006), która dokonała charakterystyki Inwentarza do Oceny Płci Psychologicznej. Przy ocenie trafności teoretycznej inwentarza skorzystała $\mathrm{z}$ analizy czynnikowej. Dzięki temu udało jej się wyodrębnić dwa czynniki: I (Kobiecość) i II (Męskość), które skupiają w sobie cechy stereotypowo przypisane danej płci w oryginalnym badaniu Kuczyńskiej (1992). Tu I czynnik wyjaśnia $17,42 \%$ wariancji, a II $16,82 \%$. Jest to odwrotna tendencja w porównaniu z powyższym badaniem.

W skali Kobiecości istnieje pewna analogia jeśli chodzi o wysokość ładunków poszczególnych pozycji. W przypadku następujących określeń: delikatny $(0,76)$, uczuciowy $(0,82)$, czuły $(0,78)$ są one zbliżone do ładunków pozycji w powyższej analizie (patrz: tabela 4). Istnieje też pewna tendencja, która znalazła w niej potwierdzenie. Mianowicie z badań R. Korzeń (2006) wynika, że takie pozycje jak: gderliwy czy naiwny mające niskie ładunki $(0,09 ; 0,19)$ nie zmieściły się w Kobiecości, tu zachodzi ten sam proces. Ponadto pozycja: mający poczucie estetyki $(0,48)$ dziś ma ładunek o wartości $(0,31)$. Z kolei, gospodarny $(0,32)$ o niskim ładunku, obecnie zajmuje miejsce poza stereotypem Kobiecości, a odnajduje się na przeciwnym biegunie (skala Męskości). Uwidacznia się pewien proces ewolucji cech, które niegdyś przypisywane wyłącznie kobietom, dziś przechodzą do Męskości.

$\mathrm{W}$ tej skali najsilniejszymi pozycjami są: pewny siebie $(0,76)$ oraz majacy site przebicia $(0,75)$ (Korzeń, 2006). Obecnie siła ładunków jest nieznacznie niższa, w tych dwóch przypadkach. W badaniach tejże autorki przymiotniki (dla Męskości) przyjmują wartości w przedziale od 0,37 do 0,76. Z czego jedynie: arogancki czy majacy dobra kondycje fizyczna nie przekraczają 0,40. W obecnej analizie, pierwsza pozycja nie zmieściła się w żadnej ze skal, druga natomiast przyjmuje wartość: $(0,34)$. Ponadto, w skali Męskości widoczne jest obniżenie ładunków dla takich pozycji jak: niezależny, rywalizujący, $z$ poczuciem humoru, samowystarczalny, eksperymentujacy $w \dot{z} y c i u$ seksualnym. Cechy takie jak: kokieteryjny czy dbający o swój wygląd, które Korzeń zaklasyfikowała jako uniwersalne, obecnie znalazły swe miejsce w skali Męskości, chociaż ich ładunki nie są wysokie. Możliwe, że jest to związane z pewną asymetrią w zakresie płci wynikającą z androcentryzmu (Bem, 2000, s.153) gdzie mężczyźni mają tendencję do afirmowania i doceniania własnej cielesności, a kobiety raczej do jej niedoceniania (Bem, 2000, s.153), Ponadto, określenie otwarty na świat zdarzeń zewnętrznych u autorki zasila Kobiecość. Zaskakujące jest też to, że 
określenie gospodarny ma ładunek o wartości $(0,43)$ i również zasilił ową Męskość (patrz: tabela 4). Być może zjawisko to jest efektem „transpozycji” cech, które dotychczas utożsamiane z kobiecością obecnie wzbogacają stereotyp męskości.

Tabela 5

Porównanie wartości ładunków pozycji z własnego badania oraz charakterystyki Renaty Korzeń (2006)

\begin{tabular}{|c|c|c|c|c|}
\hline & \multicolumn{2}{|c|}{$\begin{array}{c}\text { Badania własne; } \\
\text { Analiza macierzy korelacji, z rotacją } \\
\text { ortogonalną Varimax }\end{array}$} & \multicolumn{2}{|c|}{$\begin{array}{c}\text { Nowa charakterystyka IPP - Renata } \\
\text { Korzeń (2006); } \\
\text { Analiza czynnikowa }\end{array}$} \\
\hline & Kobiecość & Męskość & Kobiecość & Męskość \\
\hline Dominujący & &, 537 & $-0,04$ & 0,64 \\
\hline Wrażliwy & ,651 & & 0,65 & $-0,24$ \\
\hline $\begin{array}{l}\text { Angażujący się w } \\
\text { sprawy innych }\end{array}$ & ,613 & & 0,53 & 0,05 \\
\hline Niezależny & &, 343 & $-0,06$ & 0,54 \\
\hline Troskliwy & ,681 & & 0,73 & $-0,02$ \\
\hline Łagodny &, 534 & & 0,40 & $-0,30$ \\
\hline Rywalizujący & & ,329 & $-0,05$ & 0,52 \\
\hline Nastawiony na sukces & &, 550 & 0,06 & 0,55 \\
\hline Kokieteryjny & & ,390 & 0,34 & 0,32 \\
\hline Mający siłę przebicia & & ,708 & 0,12 & 0,75 \\
\hline $\begin{array}{l}\text { Łatwo podejmujący } \\
\text { decyzję }\end{array}$ & &, 580 & $-0,05$ & 0,52 \\
\hline $\begin{array}{l}\text { Dbający o swój } \\
\text { wygląd }\end{array}$ & & ,349 & 0,38 & 0,27 \\
\hline Gospodarny & & ,428 & 0,32 & 0,18 \\
\hline Arogancki &,- 497 & & $-0,30$ & 0,37 \\
\hline Uczuciowy & ,705 & & 0,82 & $-0,08$ \\
\hline $\begin{array}{l}\text { Mający dobrą } \\
\text { kondycję fizyczną }\end{array}$ & & ,343 & 0,03 & 0,38 \\
\hline Gderliwy & & & $-0,01$ & 0,09 \\
\hline $\mathrm{Z}$ poczuciem humoru & & ,335 & 0,21 & 0,44 \\
\hline Sprytny & & ,630 & 0,04 & 0,62 \\
\hline $\begin{array}{l}\text { Mający zdolność } \\
\text { przekonywania }\end{array}$ & & ,641 & 0,20 & 0,62 \\
\hline $\begin{array}{l}\text { Mający poczucie } \\
\text { estetyki }\end{array}$ &, 311 & & 0,48 & 0,12 \\
\hline Pewny siebie & & ,722 & 0,02 & 0,76 \\
\hline $\begin{array}{l}\text { Wrażliwy na potrzeby } \\
\text { innych }\end{array}$ & 655 & & 0,77 & $-0,08$ \\
\hline Samowystarczalny & & ,376 & $-0,17$ & 0,43 \\
\hline Zdolny do poświęceń &, 430 & & 0,54 & 0,02 \\
\hline
\end{tabular}




\begin{tabular}{|c|c|c|c|c|}
\hline & \multicolumn{2}{|c|}{$\begin{array}{c}\text { Badania własne; } \\
\text { Analiza macierzy korelacji, z rotacją } \\
\text { ortogonalną Varimax }\end{array}$} & \multicolumn{2}{|c|}{$\begin{array}{c}\text { Nowa charakterystyka IPP - Renata } \\
\text { Korzeń (2006); } \\
\text { Analiza czynnikowa }\end{array}$} \\
\hline & Kobiecość & Męskość & Kobiecość & Męskość \\
\hline $\begin{array}{l}\text { Otwarty na świat } \\
\text { zdarzeń zewnętrznych }\end{array}$ & ,377 & ,456 & 0,45 & 0,36 \\
\hline Delikatny & ,723 & & 0,76 & $-0,20$ \\
\hline $\begin{array}{l}\text { Eksperymentujący w } \\
\text { życiu seksualnym }\end{array}$ & & ,339 & 0,03 & 0,52 \\
\hline Naiwny & &,- 347 & 0,19 & $-0,27$ \\
\hline Czuły & ,729 & & 0,78 & $-0,04$ \\
\hline
\end{tabular}

Wskaźnik alfa Cronbacha wynosi 0,76 (w badaniu własnym) dla Kobiecości, jest ona nieco niższa niż w oryginale $(0,79)$ (Kuczyńska, 1992). Z kolei, skala Męskości ma rzetelność równą 0,77, w pierwotnej wersji: 0,78. Dla Kobiecości $S x$ jest równe 7,31 a SEM wynosi 3,58. Z kolei, w Męskości: Sx równe jest 7,72 a SEM ma wartość 3,70 (patrz: tabela 6).

W skali Kobiecości, takie pozycje jak: dbajacy o swój wygląd, tagodny, mający poczucie estetyki, kokieteryjny, gospodarny, gderliwy czy zdolny do poświęceń słabo korelują z całą skalą, ich wartości są niższe niż 0,5 . W Nowej Charakterystyce Inwentarza Renaty Korzeń (2006) jedynie cechy takie jak gderliwy czy naiwny słabo korelują ze skalą. W tym przypadku gospodarny $(0,12)$ ma niższy ładunek niż określenie naiwny $(0,18)$.

W skali Męskości większość pozycji ma niezadowalającą moc dyskryminacyjną. Nie przekraczają one progu 0,5 .

Warto podkreślić, że w oryginalnej wersji IPP podstawą oceny były współczynniki korelacji punktowo-czteropolowej phi (Brzeziński, 1978, za: Kuczyńska, 1992). Z eksperymentalnej wersji Inwentarza usunięto te pozycje, dla których wartość phi była niższa od 0,23, przy $a=0,05$ (Kuczyńska, 1992).

Tabela 6

Statystki opisowe dla Skal Kobiecości i Męskości

\begin{tabular}{ccccccccc}
\hline \multicolumn{2}{c}{ Badanie własne (analiza IPP) } & $\begin{array}{c}\text { Inwentarz do Oceny Płci } \\
\text { Psychologicznej }- \text { A. Kuczyńska }\end{array}$ & $\begin{array}{c}\text { Nowa charakterystyka } \\
\text { psychometryczna IPP }- \text { Renata } \\
\text { Korzeń (2006) }\end{array}$ \\
\hline $\mathrm{S} x=7,31$ & $\mathrm{SEM}=3,58$ & $\mathrm{R} t t=0,76$ & $\mathrm{~S} x=7,26$ & $\mathrm{SEM}=3,36$ & $\mathrm{R} t t=0,79$ & $\mathrm{~S} x=7,47$ & $\mathrm{SEM} ?$ & $\mathrm{R} t t=0,81$ \\
$\mathrm{~S} x=7,72$ & $\mathrm{SEM}=3,70$ & $\mathrm{R} t t=0,77$ & $\mathrm{~S} x=8,06$ & $\mathrm{SEM}=3,75$ & $\mathrm{R} t t=0,78$ & $\mathrm{~S} x=8,24$ & $\mathrm{SEM} ?$ & $\mathrm{R} t t=0,82$ \\
\hline
\end{tabular}


Porównanie to pokazuje, że oryginalne narzędzie: Inwentarz do Oceny Płci Psychologicznej Kuczyńskiej ma zadowalające wartości psychometryczne. Nie różnią się one znacząco w poszczególnych analizach (1992). Interpretacja wartości ładunków czynnikowych poszczególnych pozycji pokazuje, że niektóre z nich mają tendencje do przenikania się. W charakterystyce Korzeń część z nich stała się uniwersalna (2006). Ich wartości nie różnią się znacznie pomiędzy dwoma czynnikami. Większość tendencji, jeśli chodzi o niektóre określenia, potwierdza się - część z nich przestaje być wykorzystywana zarówno przez kobiety jak i mężczyzn do opisu siebie, bądź opisują ich one w niewielkim stopniu (Korzeń, 2006).

\section{Zakończenie}

Podsumowując - na początku starano się określić strukturę wewnętrzną owego Inwentarza. Wyodrębniono dwa czynniki, które wyjaśniały 30, 51\% całkowitej wariancji. Dokonano także analizy z rotacją ortogonalną czynników w metodzie Varimax, przy czym skale zostały zasilone przez pozycje o ładunku czynnikowym przekraczającym próg 0.3. W skali Kobiecości pozycjami, które charakteryzują się najwyższymi ładunkami są: czuły $(0,73)$, delikatny $(0,72)$, uczuciowy $(0,71)$. Z kolei w skali Męskości mowa o takich określeniach jak: pewny siebie $(0,72)$ oraz mający siłe przebicia $(0,71)$. Zauważono, że stereotyp męskości obfituję w większą liczbę określeń, taka sama tendencja wystąpiła na etapie tworzenia narzędzia przez Alicję Kuczyńską. W badaniach własnych Męskość zasiliło 17 pozycji a Kobiecość 10 przymiotników. Ponadto obydwa czynniki mają podobną siłę. Warto zwrócić uwagę na to, że takie pozycje jak: kokieteryjny $(0,39)$, dbający o swój wygląd $(0,35)$ oraz gospodarny $(0,43)$,przeszły” z Kobiecości do Męskości. Fakt ten jest zastanawiający. Być może jest to spowodowane kryzysem męskości, który opisuje Melosik (2006). Mężczyźni pogubili się niejako $\mathrm{w}$ pełnionych przez siebie rolach. $\mathrm{Z}$ jednej strony wymaga się od nich bycia „męskimi” w stereotypowym rozumieniu, co wiąże się z siłą, pewnością siebie, operatywnością, z drugiej zaś, oczekuje się od nich bycia wrażliwymi, ciepłymi, inaczej „kobiecymi” (2006). Możliwe jest także, że obecna sytuacja społeczno-gospodarcza wymaga by ci przedefiniowali koncepcję własnej męskości, której zastały obraz, wydaje się być nieadekwatny. Pierwsze dwa określenia kojarzą się z byciem atrakcyjnym, prawdopodobnie wygląd jest dla mężczyzn ważnym aspektem funkcjonowania, jednakże zaskakujące jest to, że określenie: dbający o swój wygląd nie zasiliło stereotypu kobiecości. Warto też jednak zwrócić uwagę, że przymiotniki znajdujące się w Inwentarzu sformułowane są w formie 
męskiej. To potwierdza niejako zjawisko androcentryzmu, jednak narzędzie powinno być od tego wolne, inaczej może stać się nieobiektywną miarą.

Powyższe analizy porównano z charakterystyką psychometryczną owego narzędzia, dokonaną przez Renatę Korzeń. Zestawienie obydwu analiz pokazuje, że IPP ma zadowalające własności psychometryczne a uzyskane wyniki różnią się nieznacznie pomiędzy sobą. To co istotne wartości ładunków czynnikowych określonych pozycji wskazują, że część z nich ,przeszła” niejako z jednego stereotypu na drugi. Niektóre miały charakter uniwersalny, oznacza to, że ich wartości, w poszczególnych czynnikach, nie różniły się znacząco między sobą, podobnie było u Renaty Korzeń. Oznacza to, że niektóre określenia przestają być wykorzystywane, zarówno przez kobiety jak i mężczyzn, do opisu siebie.

\section{Literatura cytowana}

Bem, S. L. (2000). Męskość-kobiecość. O różnicach wynikajacych z ptci. Gdańsk: Gdańskie Wydawnictwo Psychologiczne.

Korzeń, R. (2006). Nowa charakterystyka psychometryczna Inwentarza do Oceny Płci Psychologicznej (IPP). Studia Psychologica, 6, 37-50.

Kuczyńska, A. (1992). Inwentarz do oceny Ptci Psychologicznej. Warszawa: Pracownia Testów Psychologicznych PTP.

Maruszewski, T., Ścigała, E. (1998). Emocje-Aleksytymia-Poznanie. Poznań: Wydawnictwo Fundacji Humaniora, s. 133-148, 181-206.

Melosik, Z. (2006). Kryzys męskości w kulturze wspótczesnej. Kraków: Oficyna Wydawnicza Impuls. Seligman, M. E. P., Walker, E. F., Rosenhan, D., L. (2003). Psychopatologia. Poznań: Wydawnictwo Zysk i S-ka. 